\title{
Sweet taste receptors as a tool for an amplifying pathway of glucose-stimulated insulin secretion in pancreatic $\beta$ cells
}

\author{
Jae-Hyung Park ${ }^{1} \cdot$ Dae-Kyu Song $^{1}$ (D)
}

Received: 3 March 2019 / Accepted: 7 March 2019 / Published online: 15 March 2019

(C) Springer-Verlag GmbH Germany, part of Springer Nature 2019

Humans can identify several tastes, including sweet, salty, umami, bitter, and sour. Taste receptor cells in taste buds of the tongue are responsible for taste processing. There are four subtypes of taste receptor cells. Type I cells are responsible for salty taste. Type II cells are responsible for sweet, umami, and bitter tastes. Type III cells are responsible for sour taste. Type IV cells might be progenitor taste cells [7]. Type II cells express two classes of G protein-coupled receptors (GPCR): the taste 1 receptor (T1R) and the taste 2 receptor (T2R) [3]. Especially, two subtypes of T1R including T1R member 2 (T1R2) and T1R member 3 (T1R3) have been identified as sweet taste receptors [17]. Various sweet compounds, such as glucose, fructose, sucrose, maltose, D-tryptophan, D-phenylalanine, D-serine, monellin, brazzein, thaumatin, and artificial sweeteners, can activate sweet taste receptors (STR) [8]. Activation of STR stimulates phospholipase C (PLC) $\beta 2$, leading to increase of intracellular $\mathrm{Ca}^{2+}$ and activation of transient receptor potential cation channel M5 (TRPM5). These stimulate ATP releasing, leading to activation of sensory afferent neurons [5].

It has been reported that STR is expressed throughout the body, not only in taste buds, but also in gastrointestinal epithelium, pancreatic islet cells, and even neurons $[2,9,15]$. In the gastrointestinal tract, STR is mainly expressed in enteroendocrine cells [6]. These enteroendocrine cells affect appetite, gastric emptying, gastric secretion, pancreatic endocrine secretion, and

Jae-Hyung Park

physiopark@naver.com

Dae-Kyu Song

dksong@kmu.ac.kr; dksong@dsmc.or.kr

1 Department of Physiology \& Obesity-mediated Disease Research Center, Keimyung University School of Medicine, 1095

Dalgubeoldaero, Dalseogu, Daegu 42601, South Korea modulation of immune responses by secreting various bioactive peptides like ghrelin, nesfatin-1, 5-hydroxytryptamine, cholecystokinin, glucagon-like peptide (GLP)-1, and peptide YY [20]. Glucose in gastrointestinal tract leads to the release of these peptides from enteroendocrine cells $[1,18]$. Young et al. [21] demonstrated that activation of STR in enteroendocrine cells led to stimulation of GLP-1 secretion, resulting in upregulation of the $\mathrm{Na}^{+}$-dependent glucose transporter type 1 (SGLT-1). In addition, transcript levels of STR were significantly reduced in jejunal glucose-perfused mice, as well as type 2 diabetic patients. T1R plays a role in glucose-induced upregulation of SGLT-1 and glucose transporter type 2 (GLUT2) as well as GLP-1 secretion in gastrointestinal tract $[6,14]$. These results suggest that STR in the gastrointestinal tract might play important roles in nutrient or glucose sensing which helps to regulate body energy and immune balance.

STR in the hypothalamus also plays a pivotal role in nutrient sensing with similar mechanism to that of gastrointestinal tract. T1R2 and T1R3-expressed neurons might be non-proopiomelanocortin (non-POMC), leptinresponding neurons in appetite center of the hypothalamus. And STR in the hypothalamus acts as a nutrient sensor and serves to regulate energy balance, glucose homeostasis, and food intake in the brain [10].

As STR, T1R2 and T1R3 are expressed in pancreatic $\beta$ cells [15]. Kyriazis et al. [11] demonstrated that T1R2 is responsible for fructose-induced insulin release, and fructoseinduced activation of T1R2 potentiates glucose-stimulated insulin secretion in human and mouse islets. Also, T1R2 signaling in $\beta$ cells is involved in the activation of PLC and TRPM5. Nakagawa et al. [16] demonstrated that various sweet molecules increase insulin secretion via T1R3, and activation of T1R3 potentiates glucose-stimulated insulin secretion through rapid increasing of cytoplasmic $\mathrm{Ca}^{2+}$ and cyclic AMP in MIN6 cells and mouse islets. Recently, the role of T1R3 in potentiating glucose-stimulated insulin secretion was further 
demonstrated by measurement of bioelectrical activity in pancreatic $\beta$ cells [19]. Sanchez-Andres et al. [19] demonstrated that sucralose, a non-caloric artificial sweetener, had no effect on insulin secretion in the absence of glucose but induced on occasion electrical activity in mouse $\beta$ cells exposed to low non-stimulatory concentrations of the hexose and potentiated, in a concentration-related manner, the response to stimulatory concentrations of glucose. These reports suggest that STR in pancreatic $\beta$ cells acts as nutrient or glucose sensors and serves to regulate insulin secretion by possibly sensing postprandial nutrients or glucose.

It has been known that sweet compounds including sugars could potentiate glucose-stimulated insulin secretion. In healthy subjects, an orally administered disaccharide (sucrose) potentiated glucose-stimulated insulin release as compared with oral glucose ingestion alone [4] and induced a sustained increase in plasma insulin levels but not sucralose alone [12]. However, exact mechanism was unknown. One explanation is that sweet compounds are natural ligands for STR which expressed on plasma membrane in pancreatic $\beta$ cells. Pancreatic STR may allosterically sense circulating nutrients and activate a rapid signaling pathway that potentiates glucose-stimulated insulin secretion (an amplifying pathway). In addition, after a meal, intestinal STR, as a nutrient or glucose sensor, stimulates GLP-1 secretion [6, 13, 14], suggesting that a STR-dependent intestine-pancreatic axis that takes part in the regulation of postprandial insulin secretion by dietary sugars. Although endogenous ligands have not been clarified for the pancreatic STR, glucose may be a candidate as a natural ligand to amplify its own metabolism in $\beta$ cells. These receptors are GPCR to increase intracellular ATP levels when activated in the presence of glucose. Besides, veiled amplifying signaling pathways for insulin secretion may exist through this receptor. It is interesting that heterogeneity of the beta cell response to sucralose in the presence of subthreshold glucose levels can be partially erased in the presence of suprathreshold glucose levels. The authors [19] suggest that this reason may be because of a heterogeneous STR constitution in $\beta$-cells, which exhibits differential sensitivity to ligands. The authors [19] further hypothesize that human diabetic patients who have impaired $\beta$-cell glucose sensitivity may possess abnormal sensitivity of $\beta$-cell STR to glucose, similar to that in enteroendocrine cells.

\section{References}

1. Baggio LL, Drucker DJ (2007) Biology of incretins: GLP-1 and GIP. Gastroenterology 132:2131-2157. https://doi.org/10.1053/j. gastro.2007.03.054
2. Bezencon C, le Coutre J, Damak S (2007) Taste-signaling proteins are coexpressed in solitary intestinal epithelial cells. Chem Senses 32:41-49. https://doi.org/10.1093/chemse/bj1034

3. Chaudhari N, Roper SD (2010) The cell biology of taste. J Cell Biol 190:285-296. https://doi.org/10.1083/jcb.201003144

4. Crapo PA, Reaven G, Olefsky J (1976) Plasma glucose and insulin responses to orally administered simple and complex carbohydrates. Diabetes 25:741-747

5. Depoortere I (2014) Taste receptors of the gut: emerging roles in health and disease. Gut 63:179-190. https://doi.org/10.1136/gutjnl2013-305112

6. Jang HJ, Kokrashvili Z, Theodorakis MJ, Carlson OD, Kim BJ, Zhou J, Kim HH, Xu X, Chan SL, Juhaszova M, Bernier M, Mosinger B, Margolskee RF, Egan JM (2007) Gut-expressed gustducin and taste receptors regulate secretion of glucagon-like peptide-1. Proc Natl Acad Sci U S A 104:15069-15074. https:// doi.org/10.1073/pnas.0706890104

7. Janssen S, Depoortere I (2013) Nutrient sensing in the gut: new roads to therapeutics? Trends Endocrinol Metab 24:92-100. https://doi.org/10.1016/j.tem.2012.11.006

8. Jiang P, Cui M, Zhao B, Snyder LA, Benard LM, Osman R, Max M, Margolskee RF (2005) Identification of the cyclamate interaction site within the transmembrane domain of the human sweet taste receptor subunit T1R3. J Biol Chem 280:34296-34305. https://doi. org/10.1074/jbc.M505255200

9. Kohno D (2017) Sweet taste receptor in the hypothalamus: a potential new player in glucose sensing in the hypothalamus. J Physiol Sci 67:459-465. https://doi.org/10.1007/s12576-017-0535-y

10. Kohno D, Koike M, Ninomiya Y, Kojima I, Kitamura T, Yada T (2016) Sweet taste receptor serves to activate glucose- and leptinresponsive neurons in the hypothalamic arcuate nucleus and participates in glucose responsiveness. Front Neurosci 10:502. https:// doi.org/10.3389/fnins.2016.00502

11. Kyriazis GA, Soundarapandian MM, Tyrberg B (2012) Sweet taste receptor signaling in beta cells mediates fructose-induced potentiation of glucose-stimulated insulin secretion. Proc Natl Acad Sci U S A 109:E524-E532. https://doi.org/10.1073/pnas.1115183109

12. Ma J, Bellon M, Wishart JM, Young R, Blackshaw LA, Jones KL, Horowitz M, Rayner CK (2009) Effect of the artificial sweetener, sucralose, on gastric emptying and incretin hormone release in healthy subjects. Am J Physiol Gastrointest Liver Physiol 296: G735-G739. https://doi.org/10.1152/ajpgi.90708.2008

13. Mace OJ, Affleck J, Patel N, Kellett GL (2007) Sweet taste receptors in rat small intestine stimulate glucose absorption through apical GLUT2. J Physiol 582:379-392. https://doi.org/10.1113/ jphysiol.2007.130906

14. Margolskee RF, Dyer J, Kokrashvili Z, Salmon KS, Ilegems E, Daly K, Maillet EL, Ninomiya Y, Mosinger B, Shirazi-Beechey SP (2007) T1R3 and gustducin in gut sense sugars to regulate expression of Na+-glucose cotransporter 1. Proc Natl Acad Sci U S A 104:15075-15080. https://doi.org/10.1073/pnas.0706678104

15. Nakagawa $\mathrm{Y}$, Nagasawa M, Yamada S, Hara A, Mogami H, Nikolaev VO, Lohse MJ, Shigemura N, Ninomiya Y, Kojima I (2009) Sweet taste receptor expressed in pancreatic beta-cells activates the calcium and cyclic AMP signaling systems and stimulates insulin secretion. PLoS One 4:e5106. https://doi.org/10.1371/ journal.pone.0005106

16. Nakagawa Y, Nagasawa M, Medina J, Kojima I (2015) Glucose evokes rapid $\mathrm{Ca} 2+$ and cyclic AMP signals by activating the cell-surface glucose-sensing receptor in pancreatic beta-cells. PLoS One 10:e0144053. https://doi.org/10.1371/ journal.pone. 0144053

17. Nelson G, Hoon MA, Chandrashekar J, Zhang Y, Ryba NJ, Zuker CS (2001) Mammalian sweet taste receptors. Cell 106:381-390 
18. Raybould HE (2007) Sensing of glucose in the gastrointestinal tract. Auton Neurosci 133:86-90. https://doi.org/10.1016/j.autneu.2007. 01.006

19. Sanchez-Andres JV, Malaisse WJ, Kojima I (2018) Electrophysiology of the pancreatic islet beta-cell sweet taste receptor TIR3. Pflugers Arch. https://doi.org/10.1007/s00424-0182237-6

20. Strader AD, Woods SC (2005) Gastrointestinal hormones and food intake. Gastroenterology 128:175-191
21. Young RL, Sutherland K, Pezos N, Brierley SM, Horowitz M, Rayner CK, Blackshaw LA (2009) Expression of taste molecules in the upper gastrointestinal tract in humans with and without type 2 diabetes. Gut 58:337-346. https://doi.org/10.1136/gut.2008. 148932

Publisher's note Springer Nature remains neutral with regard to jurisdictional claims in published maps and institutional affiliations. 